\title{
Genetic diversity of carrot (Daucus carota L.) cultivars revealed by analysis of SSR loci
}

\author{
Rafal Baranski • Anna Maksylewicz-Kaul • \\ Thomas Nothnagel $\cdot$ Pablo F. Cavagnaro • \\ Philipp W. Simon • Dariusz Grzebelus
}

Received: 25 July 2011 / Accepted: 17 November 2011/Published online: 29 November 2011

(C) The Author(s) 2011. This article is published with open access at Springerlink.com

\begin{abstract}
Polymorphism of simple sequence repeat (SSR) loci was assessed in a collection of 88 carrot (Daucus carota L. subsp. sativus Hoffm.) accessions. The collection comprised cultivars and landraces mainly from Asia, Europe, and North America. Plants were grown in the glasshouse and characterized for root color and shape. Thirty SSR loci were fully characterized using parameters derived from allele frequencies, i.e. the number of total, effective and rare alleles, the observed and expected heterozygosity, and fixation index. Using a Bayesian approach, two clusters of 17 and 61 accessions were distinguished, which comprised the Asian and Western type
\end{abstract}

Electronic supplementary material The online version of this article (doi:10.1007/s10722-011-9777-3) contains supplementary material, which is available to authorized users.

R. Baranski ( $\square)$ · A. Maksylewicz-Kaul · D. Grzebelus Department of Genetics, Plant Breeding and Seed Science, University of Agriculture in Krakow, Al. 29 Listopada 54, 31425 Krakow, Poland e-mail: r.baranski@ogr.ur.krakow.pl

T. Nothnagel

Institute for Breeding Research on Horticultural and Fruit Crops, Federal Research Centre for Cultivated PlantsJulius Kühn-Institut, Erwin-Baur-Str. 27, 06484 Quedlinburg, Germany

P. F. Cavagnaro · P. W. Simon

USDA-ARS Vegetable Research Crops Unit, Department of Horticulture, University of Wisconsin-Madison,

1575 Linden Drive, Madison, WI 53706, USA accessions, respectively. Genetic diversity of the Asian gene pool was higher than that of the Western gene pool. The results of SSR analysis were supported by morphological characterization, and are congruent with current knowledge on the history of carrot domestication and breeding.

Keywords Biodiversity - Daucus carota .

Gene bank $\cdot$ Microsatellites $\cdot$ Molecular markers

\section{Introduction}

Edible carrot (Daucus carota L. subsp. sativus Hoffm.) is an important vegetable grown worldwide. It is one of the main sources of dietary pro-vitamin A carotenoids (Simon 1990). Variation in the carotenoid content and

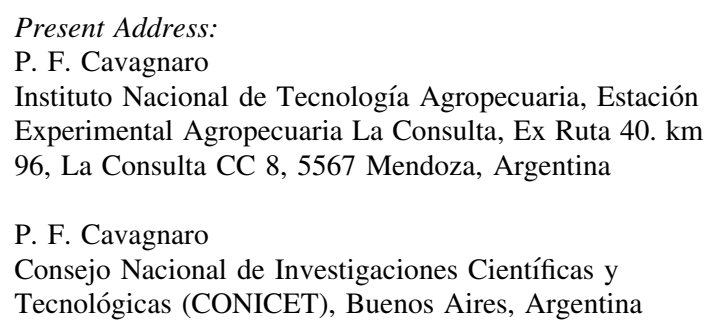


composition largely depends on the cultivar, resulting in roots of various shapes and white, yellow, orange, or red color, which can be masked by purple anthocyanins (Baranski et al. 2011). Historical data indicate that edible carrot originated in the Afghanistan region before the tenth century. Those old carrots, known as Eastern carrots, were yellow- or purple-rooted. Their cultivation spread to central and north Asia, and then to Japan (seventeenth century). Near East is commonly accepted as the secondary centre of diversity of cultivated carrots. In contrast to Eastern carrots, Western carrots are characterized by having less pubescent leaves and lower tendency to early flowering. Yellow and purple carrots were grown in Europe in the Middle Ages, but then they were gradually replaced by white and then orange-rooted forms, which appeared in the early seventeenth century, presumably as a result of selection from yellow carrot and/or hybridization of cultivated carrot and its wild relatives (Rubatzky et al. 1999). Orange-rooted carrots spread from Europe to other continents and became predominant in the commercial production worldwide. Carrots of other root color are more commonly grown in Asia and just recently they have been reintroduced to European and American specialty markets (Simon et al. 2008). A long history of carrot selection and the use of diverse parental materials in breeding programs throughout the world have resulted in considerable variation in available cultivars. Additionally, allogamy and easy hybridization with the wild carrot make delimitation of carrot genetic pools difficult when only morphological characters are considered (Grzebelus et al. 2011). This is particularly well noted in modern advanced Western type cultivars bred to develop purple, red, or yellow roots, which combine morphological features characteristic of Asian and European, or American carrots.

Microsatellite or simple sequence repeat (SSR) markers proved to be useful in the assessment of genetic diversity of populations occurring in natural habitats and large gene bank collections, as well as in revealing relationships between crop plants and their wild relatives (Varshney et al. 2010; Kalia et al. 2011). In Daucus, most molecular techniques used to date could not uncover clear population structure (Bradeen et al. 2002), although delimitation between cultivated carrots and wild populations using AFLP markers was achieved for a small number of accessions (Shim and Jørgensen 2000). Identification of SSR loci in carrot was initiated by Niemann (2001) for linkage mapping.
Another set of SSR markers was used to study gene dispersal in wild carrot populations (Umehara et al. 2005; Rong et al. 2010). Recent results of Clotault et al. (2010) indicated that SSR markers were helpful in evaluation of genetic diversity in the cultivated carrot. However, no detailed information on the polymorphism of the SSR loci was provided in the latter report.

In the present study we assess carrot genetic diversity based on polymorphisms at 30 SSR loci in a collection of 88 cultivars and landraces. We report on a molecular evidence for divergence between Eastern (Asian) and Western (European) genetic pools.

\section{Materials and methods}

Seeds of 88 cultivated carrot (Daucus carota L. subsp. sativus Hoffm.) accessions were obtained from gene bank collections, research institutes, and breeding companies (Table 1). According to donors' information, the accessions originated from Europe (53 accessions), continental Asia (14), Japan (10), USA (5), and one accession each from Brazil, Australia, and Ethiopia. For three accessions there was no information available regarding their origin.

The plants were grown in 3:1 sand and commercial humus mixture in $19 \mathrm{~cm}$ pots. The glasshouse conditions were optimized for carrot growth, i.e. 20-25 and $10-15^{\circ} \mathrm{C}$ in days and nights, respectively, and about $60 \%$ relative humidity. Young leaves of individual plants were freeze-dried. After 105 days of vegetation, roots of the same plants were harvested and assessed for root color both at the root surface and crosssection, and root shape.

DNA was extracted from freeze-dried leaves using the CTAB method. Polymerase chain reactions were carried out in the reaction mixture of $20 \mathrm{ng}$ DNA, $0.25 \mathrm{mM}$ dNTP, $0.5 \mu \mathrm{M}$ each primer, $2 \mathrm{mM} \mathrm{MgCl}_{2}$, $0.5 \mathrm{U}$ TrueStart polymerase and $1 \times$ reaction buffer (Fermentas) using the Mastercycler Gradient (Eppendorf) thermocycler programmed 1 cycle $94^{\circ} \mathrm{C}$ 5 min., 40 cycles $\left[94^{\circ} \mathrm{C}-20 \mathrm{~s}, 48-65^{\circ} \mathrm{C}\right.$ (depending on primer used) $-30 \mathrm{~s}, 71^{\circ} \mathrm{C}-1 \mathrm{~min}$ ], final extension $72^{\circ} \mathrm{C}-5 \mathrm{~min}$. Thirty SSR markers previously developed by Niemann (2001), Rong et al. (2010), and Cavagnaro et al. (2011) were analyzed (Supplementary Table 1). The amplified fragments were separated in $6 \%$ denaturing polyacrylamide gels and detected after silver staining. 
Table 1 List of accessions and their assignment to clusters identified in this work

\begin{tabular}{|c|c|c|c|c|c|c|c|}
\hline Ref. no. & Source/no. & Name & Donor country ${ }^{\mathrm{a}}$ & Origin & Status $^{\mathrm{b}}$ & Root color ${ }^{c}$ & Cluster $^{\mathrm{d}}$ \\
\hline AS 02 & Bejo & Yellowstone & NLD & Europe & OP & Y & 1 \\
\hline AS 09 & Seminis & Anthonina & USA & USA & OP & $\mathrm{P}$ & 1 \\
\hline AS 11 & INH/126 & Blanche $1 / 2$ longue des vosges & FRA & Europe & OP & W & na \\
\hline AS 12 & WGRU/3931 & Persia No. 242 & IRN & Asia & LR & $(\mathrm{Y}) \mathrm{W}$ & na \\
\hline AS 13 & WGRU/3921 & Gelbe Rheinische & $\mathrm{DEU}$ & Europe & $\mathrm{OP}$ & $\mathrm{Y}$ & 2 \\
\hline AS 14 & DAU/315 & BL-JKI-1 & TUR & Asia & BP & $\mathrm{O}$ & 1 \\
\hline AS 15 & WGRU/11201 & Afghan Purple & USA & USA & LR & $\mathrm{P}$ & 1 \\
\hline AS 16 & DAU/437 & Senta & $\mathrm{DEU}$ & Europe & $\mathrm{OP}$ & $\mathrm{O}$ & na \\
\hline AS 18 & WGRU/5779 & Nagykallo & HUN & Europe & OP & $\mathrm{O}$ & 2 \\
\hline AS 19 & WGRU/11718 & Himuro Fuyugosi Gosun No. 2 & JPN & JPN & OP & $\mathrm{O}$ & 2 \\
\hline AS 20 & POLAN & Nantejska Polana & POL & Europe & OP & $\mathrm{O}$ & 2 \\
\hline AS 21 & MKS & Hakata Kintoki & JPN & JPN & OP & $\mathrm{R}$ & 1 \\
\hline AS 22 & WGRU/6755 & Pusa Kesar & IND & Asia & LR & $\mathrm{O}$ & 1 \\
\hline AS 23 & WGRU/6754 & Panipat Special & IND & Asia & LR & $(\mathrm{R}) \mathrm{O}$ & 1 \\
\hline AS 24 & WGRU/13238 & Syrian Purple & TUR & Asia & LR & $\mathrm{P}$ & 1 \\
\hline AS 25 & Wild & BL-JKI-2 & TUR & Asia & $\mathrm{BP}$ & $\mathrm{P}$ & 1 \\
\hline AS 27 & MKS & China Yellow & $\mathrm{CHN}$ & Asia & $\mathrm{OP}$ & $\mathrm{Y}$ & 1 \\
\hline AS 28 & WGRU/6752 & Shahpur Special & IND & Asia & LR & $\mathrm{R}$ & 1 \\
\hline AS 29 & MKS & Kokubu Senko Oonaga & JPN & JPN & OP & $\mathrm{O}$ & na \\
\hline AS 30 & MKS & Sapporo Futo & JPN & JPN & OP & $\mathrm{O}$ & 2 \\
\hline AS 31 & MKS & Shima Ninjin & JPN & JPN & OP & $\mathrm{Y}$ & 1 \\
\hline AS 32 & MKS & Hekinan Senko 5sun & JPN & JPN & OP & $\mathrm{O}$ & 2 \\
\hline AS 33 & Commercial & Amsterdam 3 & POL & Europe & OP & $\mathrm{O}$ & 2 \\
\hline AS 35 & WGRU/8720 & White Belgian & GBR & Europe & $\mathrm{OP}$ & $\mathrm{W}$ & 2 \\
\hline AS 36 & Commercial & Lobbericher & DEU & Europe & OP & $\mathrm{Y}$ & na \\
\hline AS 37 & WGRU/10146 & Gajar (10146) & PAK & Asia & LR & $\mathrm{R}$ & 1 \\
\hline AS 38 & WGRU/13403 & Mestnaya (13403) & RUS & Asia & LR & W & na \\
\hline AS 39 & JKI & BL-JKI-7 & $\mathrm{DEU}$ & Asia & $\mathrm{BP}$ & $\mathrm{P}$ & 1 \\
\hline AS 40 & JKI & BL-JKI-6 & $\mathrm{DEU}$ & Asia & $\mathrm{BP}$ & $(\mathrm{R}) \mathrm{Y}$ & 2 \\
\hline AS 41 & WGRU/10627 & Lozin 147 & CSK & Europe & OP & $\mathrm{O}$ & 2 \\
\hline AS 42 & WGRU/7125 & Delta a Cuoro Rosso & ITA & Europe & OP & $\mathrm{O}$ & 2 \\
\hline AS 43 & USDA & $\mathrm{HCM}$ & USA & USA & $\mathrm{OP}$ & $\mathrm{O}$ & 2 \\
\hline AS 44 & WGRU/8390 & Western Red & AUS & Australia & OP & $\mathrm{O}$ & 2 \\
\hline AS 45 & WGRU/3842 & Norfolk Giant & GBR & Europe & OP & $\mathrm{O}$ & 2 \\
\hline AS 46 & WGRU/9808 & Kuettiger (9808) & $\mathrm{CHE}$ & Europe & OP & W & na \\
\hline AS 47 & DAU/333 & Yellow Belgian & NLD & Europe & OP & $\mathrm{Y}$ & 2 \\
\hline AS 48 & WGRU/10480 & Bitolski & YUG & Europe & $\mathrm{OP}$ & $\mathrm{O}$ & 2 \\
\hline AS 49 & WGRU/10197 & Gajar (10197) & IND & Asia & LR & $\mathrm{O}$ & 1 \\
\hline AS 50 & WGRU/13405 & Mestnaya (13405) & RUS & Asia & LR & $(\mathrm{P}) \mathrm{Y}$ & 1 \\
\hline AS 51 & WGRU/3982 & Red Elephant & GBR & Europe & $\mathrm{OP}$ & $\mathrm{O}$ & 2 \\
\hline AS 52 & WGRU/3849 & Victa & GBR & Europe & OP & $\mathrm{O}$ & 2 \\
\hline AS 53 & WGRU/4001 & Niiza Etton Gosun & JAP & JPN & OP & $\mathrm{O}$ & 2 \\
\hline AS 54 & Bejo & Nevis & NLD & Europe & $\mathrm{OP}$ & $\mathrm{O}$ & 2 \\
\hline AS 55 & Sperli & Rotin & $\mathrm{DEU}$ & Europe & OP & $\mathrm{O}$ & 2 \\
\hline
\end{tabular}


Table 1 continued

\begin{tabular}{|c|c|c|c|c|c|c|c|}
\hline Ref. no. & Source/no. & Name & Donor country ${ }^{\mathrm{a}}$ & Origin & Status ${ }^{b}$ & Root color ${ }^{\mathrm{c}}$ & Cluster $^{\circ}$ \\
\hline AS 56 & Bejo & Vita Longa & NLD & Europe & $\mathrm{OP}$ & $\mathrm{O}$ & 2 \\
\hline AS 57 & NGB/1852 & Nantes Empire & DNK & Europe & $\mathrm{OP}$ & $\mathrm{O}$ & 2 \\
\hline AS 58 & NGB/548 & Touchon Format & DNK & Europe & $\mathrm{OP}$ & $\mathrm{O}$ & 2 \\
\hline AS 59 & NGB/1863 & Amsterdamer Master & DNK & Europe & $\mathrm{OP}$ & $\mathrm{O}$ & 2 \\
\hline AS 60 & DAU/341 & Lange Rote Stumpfe ohne Herz 1 & DEU & Europe & $\mathrm{OP}$ & $\mathrm{O}$ & 2 \\
\hline AS 61 & NGB/13970 & Nana W 561 & SWE & Europe & OP & $\mathrm{O}$ & 2 \\
\hline AS 62 & WGRU/4002 & Shinsuu Senkou Oonaga & JPN & JPN & $\mathrm{OP}$ & $\mathrm{O}$ & 2 \\
\hline AS 63 & WGRU/7801 & Benifuku Fuyngosi 5 Sun & JPN & JPN & $\mathrm{OP}$ & $\mathrm{O}$ & 2 \\
\hline AS 64 & WGRU/10626 & Stratova & CSK & Europe & $\mathrm{OP}$ & $\mathrm{O}$ & 2 \\
\hline AS 65 & DAU/326 & Nantes Half Long & $\mathrm{m}$. & Europe & $\mathrm{OP}$ & $\mathrm{O}$ & 2 \\
\hline AS 66 & WGRU/3971 & Champion Scarlet Horn & GBR & Europe & $\mathrm{OP}$ & $\mathrm{O}$ & 2 \\
\hline AS 67 & WGRU/3844 & Viking & GBR & Europe & $\mathrm{OP}$ & $\mathrm{O}$ & 2 \\
\hline AS 68 & WGRU/11157 & Berlicum Normaal & NLD & Europe & $\mathrm{OP}$ & $\mathrm{O}$ & 2 \\
\hline AS 69 & WGRU/6519 & Purple Stem Selektion & FRA & Europe & $\mathrm{OP}$ & $\mathrm{Y}$ & 2 \\
\hline AS 70 & DAU/424 & Danver's Red Core & $\mathrm{m}$. & USA & $\mathrm{OP}$ & $\mathrm{O}$ & 2 \\
\hline AS 71 & NGB/1855 & Nantes Duke & DNK & Europe & $\mathrm{OP}$ & $\mathrm{O}$ & 2 \\
\hline AS 72 & WGRU/3835 & Red Giant & GBR & Europe & $\mathrm{OP}$ & $\mathrm{O}$ & 2 \\
\hline AS 74 & Vilmorin & Texto & FRA & Europe & $\mathrm{F} 1$ & $\mathrm{O}$ & 2 \\
\hline AS 75 & Vilmorin & Presto & FRA & Europe & $\mathrm{OP}$ & $\mathrm{O}$ & 2 \\
\hline AS 76 & USDA & Beta III & USA & USA & $\mathrm{OP}$ & $\mathrm{O}$ & 2 \\
\hline AS 77 & JKI & Pariser Markt & DEU & Europe & $\mathrm{OP}$ & $\mathrm{O}$ & 2 \\
\hline AS 78 & JKI & Vitaminaja & RUS & Europe & $\mathrm{OP}$ & $\mathrm{O}$ & 2 \\
\hline AS 79 & WGRU/8863 & Cyrano & NLD & Europe & $\mathrm{OP}$ & $\mathrm{O}$ & 2 \\
\hline AS 80 & $\mathrm{DAU} / 460$ & Gold Pak & $\mathrm{m}$. & USA & $\mathrm{OP}$ & $\mathrm{O}$ & 2 \\
\hline AS 81 & Bejo & Rainbow & NLD & Europe & $\mathrm{F} 1$ & $\mathrm{O}$ & 2 \\
\hline AS 82 & Bejo & Mello Yello & NLD & Europe & $\mathrm{F} 1$ & $\mathrm{Y}$ & na \\
\hline AS 83 & WGRU/6788 & St. Valery & POL & Europe & $\mathrm{OP}$ & $\mathrm{O}$ & 2 \\
\hline AS 84 & WGRU/3955 & Sytan & FRA & Europe & $\mathrm{OP}$ & $\mathrm{O}$ & 2 \\
\hline AS 85 & NGB/551 & Nantes Liva & DNK & Europe & $\mathrm{OP}$ & $\mathrm{O}$ & 2 \\
\hline AS 86 & NGB/1849 & Flakkeer Regina & DNK & Europe & $\mathrm{OP}$ & $\mathrm{O}$ & 2 \\
\hline AS 87 & WGRU/10246 & Long Red & ETH & Africa & LR & $\mathrm{Y}$ & 1 \\
\hline AS 88 & WGRU/9325 & Winterperfection & NLD & Europe & $\mathrm{OP}$ & $\mathrm{O}$ & 2 \\
\hline AS 89 & WGRU/7884 & Stupicka k Rychleni & CSK & Europe & $\mathrm{OP}$ & $\mathrm{O}$ & 2 \\
\hline AS 90 & WGRU/7265 & Short n'Sweet & USA & USA & $\mathrm{OP}$ & $\mathrm{O}$ & na \\
\hline AS 91 & WGRU/7126 & Tropical & BRA & S-America & $\mathrm{OP}$ & $\mathrm{O}$ & na \\
\hline AS 92 & WGRU/6688 & Moskovskaja Zimniaja & RUS & Europe & $\mathrm{OP}$ & $\mathrm{O}$ & 2 \\
\hline AS 94 & WGRU/11715 & Yamanouchi Ishyaku Senko & JPN & JPN & $\mathrm{OP}$ & $\mathrm{O}$ & 2 \\
\hline AS 95 & NGB/2399 & London Torve, B Tagenshus III & DNK & Europe & $\mathrm{OP}$ & $\mathrm{O}$ & 2 \\
\hline AS 96 & WGRU/5593 & Berlicumer Bercoro & NLD & Europe & $\mathrm{OP}$ & $\mathrm{O}$ & 2 \\
\hline AS 97 & NGB/1857 & Nantes Palisade & DNK & Europe & $\mathrm{OP}$ & $\mathrm{O}$ & 2 \\
\hline AS 98 & WGRU/6085 & Berlikum Perfecta & ITA & Europe & $\mathrm{OP}$ & $\mathrm{O}$ & 2 \\
\hline AS 99 & WGRU/6026 & Beacon & GBR & Europe & $\mathrm{OP}$ & $\mathrm{O}$ & 2 \\
\hline AS 100 & NGB/13955 & Regulus Imperial & SWE & Europe & $\mathrm{OP}$ & $\mathrm{O}$ & 2 \\
\hline
\end{tabular}


Table 1 continued

\begin{tabular}{llllllll}
\hline Ref. no. & Source/no. & Name & Donor country $^{\mathrm{a}}$ & Origin & Status $^{\mathrm{b}}$ & Root color $^{\mathrm{c}}$ & Cluster $^{\mathrm{d}}$ \\
\hline Res2 & Bejo & Romosa & NLD & Europe & OP & O & 2 \\
\hline
\end{tabular}

Bejo-Bejo Zaden B.V., Warmenhuizen, The Netherlands; DAU_Leibniz Institute of Plant Genetics and Crop Plant Research, IPKGatersleben, Germany; INH-Institut National d'Horticulture et de Paysage, Angers, France; JKI-Julius Kuehn Institute, Quedlinburg, Germany; MKS—Mikado Kyowa Seed Co. Ltd., Chosei, Japan; NGB-Nordic Genetic Resource Center, Alnarp, Sweden; POLAN_Krakowska Hodowla i Nasiennictwo Ogrodnicze POLAN Ltd., Krakow, Poland; Seminis-Seminis Vegetable Seeds, Inc., Saint Louis, USA; Sperli-Saatzucht Carl Sperling \& Co. GmbH, Lüneburg, Germany; USDA-USDA-ARS, University of Wisconsin, Department of Horticulture, Wisconsin, USA; Vilmorin—Vilmorin \& Cie Co., La Ménitré, France; WGRU—Warwick Genetic Resources Unit, Warwick University, Wellesbourne, Great Britain; Wild—Rudolf Wild GmbH \& Co. KG, Berlin, Germany; commercial—seeds from shop

a Country of donor; $m-$ missing data

b $\mathrm{OP}$ - open pollinated cultivar, F1—hybrid, BL-breeding population, LR-landrace

c Color of root phloem, in brackets color of root surface if different than phloem color; $O$ orange, $Y$ yellow, $W$ white, $R$ red, $P$ purple

d Assignment to a cluster using a Bayesian approach, na not assigned

Allele frequencies were used to calculate indices of marker information content and genetic diversity implemented in GenAlEx 4.6 (Peakall and Smouse 2006); CERVUS (Kalinowski et al. 2007) and HPRARE (Kalinowski 2005). Genetic structure was investigated using a Bayesian clustering approach without information on the accession origin and assuming the admixture model and correlated allele frequencies (STRUCTURE 2.2.3; Pritchard et al. 2000). Seven independent simulations with a burn-in length of $10^{4}$ and a run length of $10^{5}$ were used for each number of clusters $\mathrm{K}$ set from 1 to 12 . For the most likely number of genetic clusters, run parameters were increased by the factor of 10. Principal coordinate analysis (PCoA), molecular variance AMOVA and an unbiased estimate of $\mathrm{F}_{\mathrm{ST}}$ jackknifing over loci were used for the assessment of genetic diversity.

\section{Results and discussion}

All 30 SSR loci were polymorphic and there were no duplicates in the collection. In total, 227 alleles were identified with a mean of 7.6 per locus (Supplementary Table 2), similar as the mean obtained for the carrot collection by Clotault et al. (2010). Most of the alleles (66\%) had frequencies below 0.1 and only $9 \%$ occurred with frequencies above 0.4. About half of the alleles $(51 \%)$ were rare (freq. $<0.05)$ and were detected in all except one locus (Supplementary Fig. 1). In 12 loci, 19 unique alleles were identified ( $8.4 \%$ of all alleles). The effective number of alleles per locus (3.17), which minimizes input of alleles with low frequencies, was less than half of the total number of alleles. The markers developed by Cavagnaro et al. (2011) were more discriminating than those reported by Rong et al. (2010) as the mean polymorphic information content (PIC) was higher for the former $(0.67 \pm 0.03$ s.e. and $0.50 \pm 0.06$ s.e., respectively) The PIC for SSR loci identified by Niemann (2001) was intermediate.

The observed heterozygosity $\left(\mathrm{H}_{\mathrm{o}}=0.33\right)$ was, on average, much lower than the expected heterozygosity $\left(\mathrm{H}_{\mathrm{e}}=0.63\right)$. The latter measure of diversity is similar to $\mathrm{H}_{\mathrm{e}}=0.73$ reported earlier for a collection of other 47 cultivars (Clotault et al. 2010). For most loci, the Wright's fixation index F was significantly higher than zero and reached up to 0.84 , indicating excess of alleles in the homozygous state that could be expected for advanced cultivars and breeding populations. The putative presence of null alleles could also contribute to high F-values although their presence in the collection was not confirmed.

A Bayesian approach for clustering accessions was applied to investigate genetic structure in the collection. Two clusters comprising 17 and 61 accessions, respectively, with the assigning probability above 0.6 were identified (Fig. 1). In addition, 10 accessions with probabilities between 0.4 and 0.6 that were initially associated ambiguously to clusters 1 or 2 were finally not assigned to either of these clusters. Cluster 1 included accessions from continental Asia (11 accessions), Japan (2), USA (2), and Ethiopia (1), all classified there with probabilities $>0.8$, and a single 


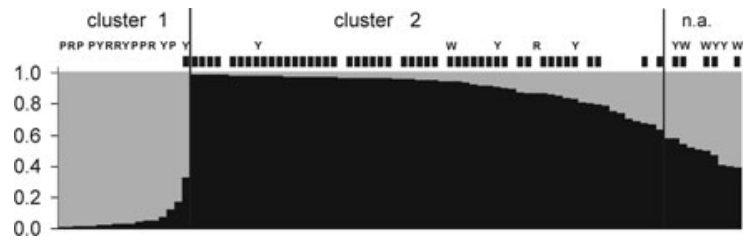

Fig. 1 Structure of the genetic diversity of the 88 carrot accessions based on a Bayesian approach and assuming two gene pools. Letters denote root color: $P$ purple, $R$ red, $W$ white, $Y$ yellow, no letter indicate orange color; squares indicate European accessions; n.a. not assigned (assignment probability 0.4-0.6)

European cultivar, 'Yellowstone', classified with lower probability (0.67). Cluster 2 included accessions from Europe (48), Japan (7), USA (4), continental Asia (1), and Australia (1). Diversity of the complete collection of 88 accessions was also revealed by PCoA (Fig. 2). The first three axes together explained $60 \%$ of the total variation, and the first axis alone $(26 \%$ variation) differentiated mainly accessions classified to cluster 1 and cluster 2 by the Bayesian approach.
The second and the third axes contributed equally to PCoA. The latter differentiated Japanese accessions from the rest.

The results of both PCoA and Bayesian clustering were highly congruent and revealed that most carrot cultivars could be separated into two genetic pools, although there was no clear delimitation between them. The first pool comprised predominantly the landraces originating from continental Asia; all of yellow, red, and purple root color; and two cultivars from Japan with red and yellow roots (Table 1). It also comprised four accessions from other world regions but developing purple roots, typical for Asian carrot. 'Yellowstone', the only European cultivar in cluster 1, and the African landrace 'Long Red' were also yellow-rooted. Thus, all accessions found in cluster 1 were directly sampled in Asia and/or had root color characteristic for that region. One of these accessions, 'Syrian Purple', was distinguished by its pubescent leaves, typical for the Eastern carrot type, whereas such trait was not observed in the remaining

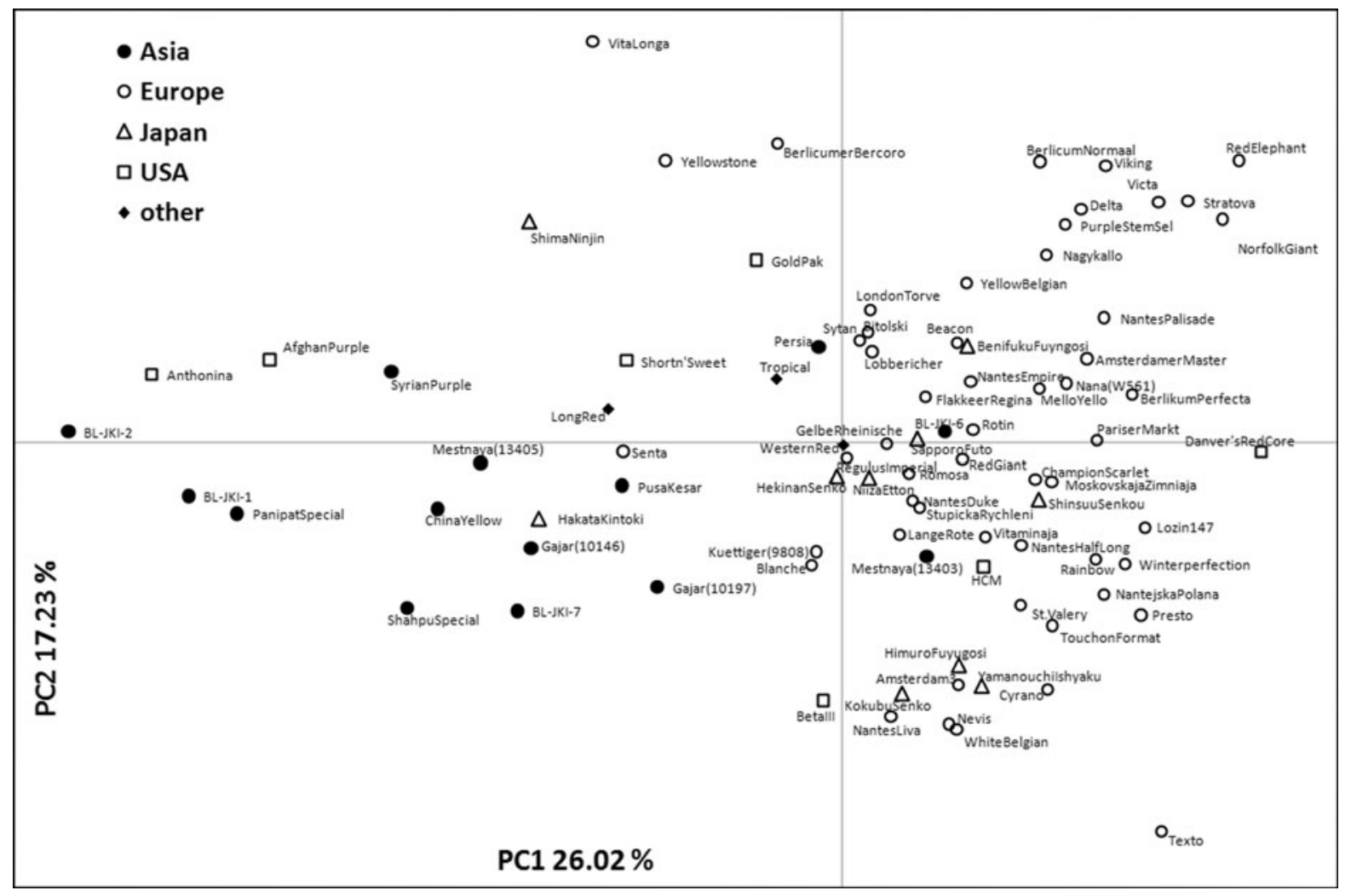

Fig. 2 PCoA of 88 carrot accessions based on polymorphism of 30 SSR loci 
Table 2 Comparative parameters of genetic diversity for two clusters

a Significant difference between clusters at

$* P<0.05$, ** $P<0.01$; $n s$ non-significant

\begin{tabular}{lccccc}
\hline Parameter & Cluster 1 & s.e. & Cluster 2 & s.e. & $P^{\text {a }}$ \\
\hline Number of accessions $(\mathrm{N})$ & 17 & & 61 & \\
Total number of alleles $\left(\mathrm{A}^{\mathrm{t}}\right)$ & 171 & & 184 & & \\
Mean number of alleles $\left(\mathrm{A}^{\mathrm{m}}\right)$ & 5.7 & 0.37 & 6.1 & 0.43 & $\mathrm{~ns}$ \\
Mean number of effective alleles $\left(\mathrm{A}^{\mathrm{e}}\right)$ & 3.6 & 0.28 & 2.8 & 0.20 & $* *$ \\
Allelic richness (R) & 5.5 & 0.35 & 4.6 & 0.29 & $* *$ \\
Number of private alleles $\left(\mathrm{A}^{\mathrm{p}}\right)$ & 34 & & 47 & & \\
Private allelic richness $\left(\mathrm{R}^{\mathrm{p}}\right)$ & 2.6 & 0.26 & 1.07 & 0.19 & $* *$ \\
Polymorphic information content (PIC) & 0.62 & 0.03 & 0.53 & 0.03 & $* *$ \\
Shannon's index (I) & 1.37 & 0.08 & 1.15 & 0.08 & $* *$ \\
Observed heterozygosity $\left(\mathrm{H}_{\mathrm{o}}\right)$ & 0.38 & 0.04 & 0.29 & 0.04 & $*$ \\
Expected heterozygosity $\left(\mathrm{H}_{\mathrm{e}}\right)$ & 0.68 & 0.03 & 0.58 & 0.03 & $* *$ \\
Fixation index $(\mathrm{F})$ & 0.44 & 0.06 & 0.48 & 0.06 & $\mathrm{~ns}$ \\
\hline
\end{tabular}

Japanese accessions observed in PCoA scatter plot is thus congruent with information on their pedigree.

The divergence of both clusters representing Asian and Western gene pools was moderate $\left(\mathrm{F}_{\mathrm{ST}}=\right.$ $0.097 \pm 0.014$ s.e. $)$ but highly significant $(P<0.01)$. Furthermore, partitioning variation using AMOVA attributed $8.8 \%(P<0.01)$ of the total genetic diversity to the variation between clusters. The cluster divergence resulted from the presence of private alleles in each cluster, but was also supported by the presence of 23 other alleles occurring with frequencies above 0.9 in one of the two clusters. Allelic richness, a useful parameter for comparison populations differing in size, was higher for cluster 1 than for cluster 2 by $20 \%$ $(P<0.01)$ (Table 2). Private allelic richness, which estimates the presence of unique alleles for a cluster, was over two-fold higher for cluster $1(P<0.01)$, although the number of private alleles was higher in cluster 2. Also other parameters, i.e. PIC, Shannon's index, $\mathrm{H}_{\mathrm{o}}$, and $\mathrm{H}_{\mathrm{e}}$ were higher for cluster 1 indicating that Asian gene pool had higher genetic diversity, which can partially result from the presence of landraces.

Acknowledgments The authors acknowledge the support of the Polish Ministry of Science and Higher Education (MNiSW 97/N-DFG/2008/0) and German Research Foundation (DFG Schu 566/10-1).

Open Access This article is distributed under the terms of the Creative Commons Attribution Noncommercial License which permits any noncommercial use, distribution, and reproduction in any medium, provided the original author(s) and source are credited. 


\section{References}

Baranski R, Allender Ch, Klimek-Chodacka M (2011) Towards better tasting and more nutritious carrots: carotenoid and sugar content variation in carrot genetic resources. Food Res Int (in press). doi:10.1016/j.foodres.2011.05.006

Bradeen JM, Bach IC, Briard M, le Clerc V, Grzebelus D, Senalik DA, Simon PW (2002) Molecular diversity analysis of cultivated carrot (Daucus carota L.) and wild Daucus populations reveals a genetically nonstructured composition. J Am Soc Hort Sci 127:383-391

Cavagnaro PF, Chung S-M, Manin S, Yildiz M, Ali A, Alessandro MS, Iorizzo M, Senalik DA, Simon PW (2011) Microsatellite isolation and marker development in carrot-genomic distribution, linkage mapping, genetic diversity analysis and marker transferability across Apiaceae. BMC Genomics 12:386

Clotault J, Geoffriau E, Linneton E, Briard M, Peltier D (2010) Carotenoid biosynthesis genes provide evidence of geographical subdivision and extensive linkage disequilibrium in the carrot. Theor Appl Genet 121:659-672

Grzebelus D, Baranski R, Spalik K, Allender C, Simon PW (2011) Daucus. In: Kole C (ed) Wild crop relatives: genomic and breeding resources. Vegetables. Springer, Berlin, pp 91-113

Kalia RK, Rai MK, Kalia S, Singh R, Dhawan AK (2011) Microsatellite markers: an overview of the recent progress in plants. Euphytica 177:309-334

Kalinowski ST (2005) HP-RARE 1.0: a computer program for performing rarefaction on measures of allelic richness. Mol Ecol Notes 5:187-189

Kalinowski ST, Taper ML, Marshall TC (2007) Revising how the computer program CERVUS accommodates genotyping error increases success in paternity assignment. Mol Ecol 16:1099-1106

Niemann M (2001) Entwicklung von Mikrosatelliten-Markern bei der Möhre (Daucus carota L.) und die Markierung eines Alternaria-Resistenzgens. Dissertation, Hannover University, Shaker Verlag, Aachen

Peakall R, Smouse PE (2006) GENALEX 6: genetic analysis in Excel. Population genetic software for teaching and research. Mol Ecol Notes 6:288-295

Peterson CE, Simon PW, Rubatzky VE, Strandberg JO (1988) Beta III carrot. HortScience 23:917

Pritchard JK, Stephens M, Donnelly P (2000) Inference of population structure using multilocus genotype data. Genetics 155:945-959

Rong J, Janson S, Umehara M, Ono M, Vrieling K (2010) Historical and contemporary gene dispersal in wild carrot (Daucus carota ssp. carota) populations. Ann Bot 106:285-296

Rubatzky VE, Quiros CF, Simon PW (1999) Carrots and related vegetable Umbelliferae. CABI, New York

Shim SI, Jørgensen RB (2000) Genetic structure in cultivated and wild carrots (Daucus carota L.) revealed by AFLP analysis. Theor Appl Genet 101:227-233

Simon PW (1990) Carrots and other horticultural crops as a source of provitamin A carotenes. HortScience 25:1495-1499

Simon PW, Wolff XY, Peterson CE, Rubatzky VE, Strandberg JO, Bassett MJ, White JM (1989) High carotene mass carrot population. HortScience 24:174-175

Simon PW, Freeman RE, Vieira JV, Boiteux LS, Briard M, Nothnagel T, Michalik M, Kwon YS (2008) Carrot. In: Prohens J, Nuez F (eds) Vegetables II: Fabaceae, Liliaceae, Solanaceae, and Umbelliferae. Handbook of plant breeding, vol 2. Springer, New York, pp 327-357

Umehara M, Eguchi I, Kaneko D, Ono M, Kamada H (2005) Evaluation of gene flow and its environmental effects in the field. Plant Biotech 22:497-504

Varshney RK, Baum M, Guo P, Grando S, Ceccarelli S, Graner A (2010) Features of SNP and SSR diversity in a set of ICARDA barley germplasm collection. Mol Breed 26:229-242 